\title{
ІНФОРМАЦІЙНО-ОБЛІКОВА СИСТЕМА СПОСТЕРЕЖЕННЯ ЗА ХВОРИМИ НА МУКОВІСЦИДОЗ
}

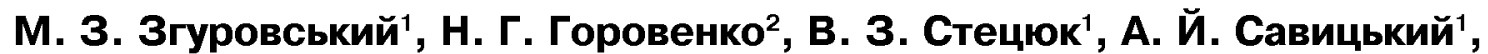 \\ Ю. І. Гладуш' ${ }^{2}$, Т. П. Іванова ${ }^{3}$, Ю. О. Луговський'1
}

Конструкторське бюро інформаційних систем національного технічного університету

України «Київський політехнічний інститут»'

Національна медична академія післядипломної освіти імені П. Л. Шупика² Національна дитяча спеціалізована лікарня "ОХМАТДИТ»з

У статті описано програмний продукт, розроблений відповідно до вимог та побажань лікарів, які працюють із хворими на муковісцидоз. Додаток розглядається як сукупність підсистем, що відповідають за різну функціональність. Описано переваги, що отримує лікар при використанні даного продукту.

Ключові слова: муковісцидоз, база даних, лікування.

\section{ИНФОРМАЦИОННО-УЧЕТНАЯ СИСТЕМА НАБЛЮДЕНИЯ БОЛЬНЫХ МУКОВИСЦИДОЗОМ}

\author{
М. 3. Згуровский' , Н. Г. Горовенкоㄹ, В. З. Стецюк'1, А. Й. Савицкий', \\ Ю. И. Гладуш' ${ }^{2}$ Т. П. Иванова ${ }^{3}$ Ю. А. Луговский'
}

Конструкторское бюро информационных систем национального технического университета Украины «Киевский политехнический институт»'

Национальная медицинская академия последипломного образования имени П.Л. Шупика ${ }^{2}$ Национальная детская специализированная больница «ОХМАТДЕТ»З

В статье описан программный продукт, разработанный в соответствии с требованиями и пожеланиями врачей, работающих с больными муковисцидозом. Приложение рассматривается как совокупность подсистем, отвечающих за разную функциональность. Описаны преимущества использования данной системы.

Ключевые слова: муковисцидоз, база данных, лечение.

\section{INFORMATION AND ACCOUNTING SYSTEM OF PATIENT MONITORING WITH CYSTIC FIBROSIS}

\author{
M. Z. Zhurovsky' ${ }^{1}$, N. H. Horovenko ${ }^{2}$, V. Z. Stetsyuk ${ }^{1}$, A. I. Savytskyi ${ }^{1}$, Yu. I. Hladush ${ }^{2}$, \\ T. P. Ivanova ${ }^{3}$, Yu. O. Luhovskyi ${ }^{1}$ \\ Design Bureau of Information Systems of the National Technical University of Ukraine "Kyiv \\ Polytechnic Institute" \\ National Medical Academy of Postgraduate Education by P. L. Shupyk ${ }^{2}$ \\ National Children's Specialized Hospital "OKHMATDYT"3
}

To assist in controlling the process of treatment and monitoring of patients was developed a software application that captures all the work with the patient. For developing this application were used medical records, statistical reporting forms, other medical documentation and doctor experience.

This software saves doctor's time, organizes their work, improves performance and allows focusing on the patient.

Key words: cystic fibrosis, database, treatment.

Вступ. Муковісцидоз (MB) - це найпоширеніше моногенне спадкове захворювання з аутосомно-ре- цесивним типом успадкування, яке можна охарактеризувати як універсальну екзокринопатію. При-

(С) М. З. Згуровський, Н. Г. Горовенко, В. З. Стецюк, А. Й. Савицький, Ю. І. Гладуш, Т. П. Іванова, Ю. О. Луговський 
родний перебіг хвороби є складним і в 80 \% випадків закінчується летально в перші роки життя. Основними проявами $\mathrm{MB} \epsilon$ хронічний обструктивний процес в дихальних шляхах, що супроводжується рекурентною бактеріальною інфекцією, порушення травної системи 3 недостатністю екзокринної функції підшлункової залози, підвищений вміст електролітів в потовій рідині та обструктивна азооспермія у чоловіків, що обумовлена вродженою агенезією сім'явиносних проток. Захворювання зустрічається у всьому світі, в переважаючій більшості у білої раси (частота 1:1200- 1:2500 новонароджених), з коливаннями від 1:1700 в Північній Ірландії та Данії до 1:25000 в Фінляндії. В Україні цей показник становить 1:2300.

Через це існує необхідність у створенні засобів, що дозволили б лікарям працювати 3 хворими на МВ.

Мета роботи: представлення програмного продукту, спрямованого на підвищення продуктивності роботи лікаря щодо надання допомоги хворим на муковісцидоз.

Матеріал і методи дослідження. Проаналізовано медичні картки, статистичні форми звітності та іншу медичну документацію, що використовується при лікуванні хворого. Аналізували способи та методи лікування хворих.

Вивчали також багаторічний досвід лікарів, які працюють із хворими на муковісцидоз. Саме він став об'єктом для інформатизації та розробки системи, що повинна спростити та структурувати роботу 3 Хворими.
Для технічної розробки використовували мову програмування C\# та сервер бази даних MS SQL. Для початку використання додатку необхідно мати операційну систему Windows XP та вище і додаткове встановлення серверу MS SQL.

Результати та їх обговорення. Результатом досліджень $\epsilon$ розроблене програмне забезпечення, що відтворюс всі етапи роботи з паціснтом.

Додаток розподіляється на частини (підсистеми), що мають різну функціональну відповідальність. Перша з них стосується даних щодо ідентифікації пацієнта та близьких родичів. Збереження суто медичної інформації здійснюється в трьох форматах: однократна фіксація (сімейний анамнез, клінічна інформація, об’єктивний статус, діагноз); динаміка зміни стану здоров'я (маса тіла, зміни на УЗД, результати лабораторного обстеження тощо); дані стаціонарних лікувань та оперативних втручань.

Динамічні зміни стану здоров'я ілюструються за допомогою графіків фізичного розвитку (рис. 1) та за допомогою зведеної таблиці даних, де представлено найважливіші поля для відстеження динаміки змінення здоров'я за певний період.

Серед інших підсистем Додатку такі:

- Обчислення. Додаток дозволяє обчислити загальну кількість лікарського засобу, необхідного для всіх пацієнтів.

- Нагадування та контроль. Створення підказок, що повідомляють про поточний стан всіх пацієнтів та їхній розклад відвідувань.

- Пошук та статистика.

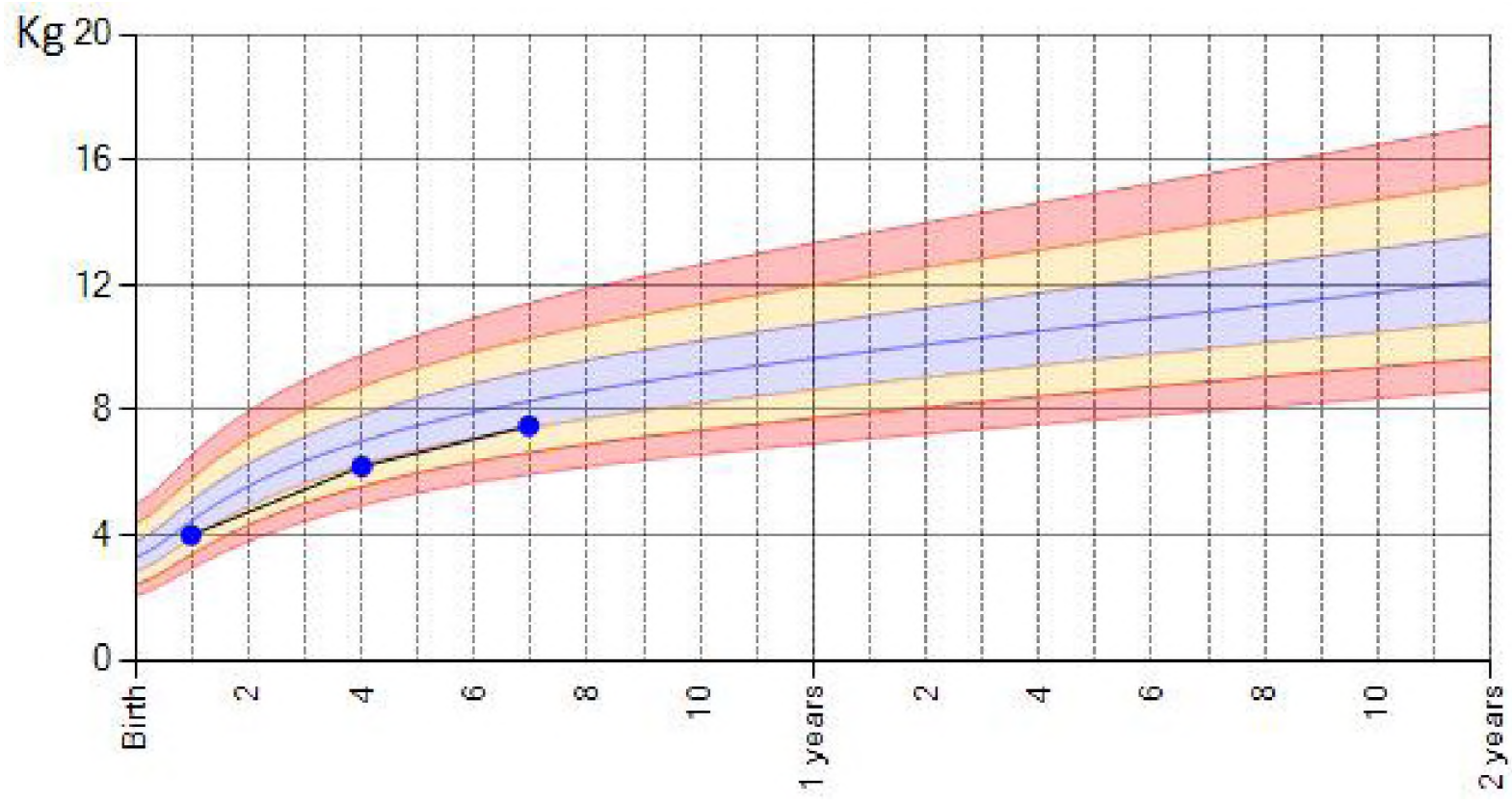

Рис. 1. Графік фізичного розвитку. 
Перша підсистема займається збереженням даних, що не несуть медичної цікавості.

Друга підсистема зберігає дані, які можна обробляти та аналізувати певним чином. Підсистема показу динамічної зміни стану здоров'я опрацьовує медичну інформацію і видає результат, що дозволяє оцінити зміни стану здоров'я і на його основі прийняти рішення стосовно лікування.

Підсистема обчислення кількості препарату дозволяє економити час та зусилля, необхідні для обчислень. Цей розрахунок проводиться на основі призначеної кількості препарату для кожного пацієнта.

Підсистема нагадування та контролю працює у фоновому режимі. Тобто записи здійснюються автоматично при збереженні даних або при перевищенні

\section{Лiтература}

1. Павловская Т. А. С\#. Программирование на языке высокого уровня : учеб. для вузов / Т. А. Павловская. - СПб. : Питер, 2007. -432 с. : ил.

2. Visual C\# 2008 : базовый курс / К. Уотсон, К. Нейгел, Д. Рид, Я. Педерсен, М. Скиннер, Э. Уайт [и др.] ; пер. с англ. Я. П. Волковой, Д. Я. Иваненко, Ю. И. Корниенко [и др.] ; зав. ред. С. Н. Тригуб̆. - М. : ООО «И. Д. Вильямс», 2009. $-1216 \mathrm{c}$ деякого часового терміну. Дана система дозволяє лікарю не тримати в голові інформацію про поточний стан здоров'я пацієнтів, призначені їм наступні візити чи дії пов'язані з його лікуванням.

Підсистема пошуку та статистики дозволяє гнучко шукати необхідну інформацію, унеможливлює помилку під час обчислення статистичних даних та дозволяс формувати звіти, шо експортуються в інші документи (файли з розширенням *.doc). Система дозволяє значно економити час лікаря.

Висновки. Розроблено програмний продукт для реєстраціі даних про хворих на муковісцидоз, що дозволяє економити час лікаря, організовує його роботу, поліпшус продуктивність.

3. Ицик Б. Microsoft Sql Server 2008. Основы T-SQL / Б. Ишик; пер. с англ. Т. Коротяевой ; глав. ред. Е. Кондукова ; зав. ред. Г. Добин. - Спб. : БХВ-Петербург, 2009. - 432 с. : ил.

4. Марк Симан. Внедрение зависимостей в .NET. - СПб. : Питер, 2013. -464 с. : ил. 